\title{
Android Based Multimedia Learning for Vocational High Schools
}

\author{
Nurhikmah Hasyim ${ }^{1}$, Hamsu Abdul Gani ${ }^{2}$, Sukarno Hatta ${ }^{3}$ \\ ${ }^{1}$ Education technology, Universitas Negeri Makassar, Indonesia \\ Email: nurhikmah.h@unm.ac.id \\ 2Education technology, Universitas Negeri Makassar, Indonesia \\ Email: hamsuabdulgani@unm.ac.id \\ ${ }^{3}$ Education technology, Universitas Negeri Makassar, Indonesia \\ Email:suekarno@gmail.com
}

(Received: June-2020; Reviewed: July-2020; Accepted: July-2020;

Available online: August-2020; Published: August-2020) CC-BY-NC-4.0 02020 by author (https://creativecommons.org/licenses/by-nc/4.0/).

\begin{abstract}
The purpose of this study was to develop an android based learning multimedia for vocational high school students in Makassar city. This is a developmental study for interactive multimedia following some stages including planning, designing, development, and attribution. The data were collected using questionnaires, interviews, and documentation and analyzed qualitatively and quantitatively with percentages. The model was developed using an alpha test by experts of media followed by experts of materials and two stages of beta test including individual and small group tests. By involving 7 students for individual trials and 25 people for small group trials, it was found that 1) the use of the internet in learning had not been optimal yet, including the use of a smartphone, while the development of information and communication technologies requires their utilization in learning, 2) android based multimedia that was developed had been validated by experts of learning content and media and was regarded valid and feasible to be applied, 3) scores resulted from individual trials were in the very feasible category so that it was regarded to be valid while the trials performed by the small groups showed scores in "valid and practical" category. Based on stages followed for the development of android based multimedia for Physics subject, the development of the product can be continued to the following stages namely big group trials and implementation.
\end{abstract}

Keywords: Android, Multimedia, Natural Science

\section{INTRODUCTION}

The use of learning media especially multimedia has many benefits for learners including to assist them to understand a material delivered by a teacher. According to Miarso (2004), learning media refers to all tools that can be used to deliver a message and can stimulate students' willingness, feeling, thinking, and attention so that it can maximize the purposeful, intentional, and controlled learning activities. The development of information and communication technologies also influences the use of media in learning. Nowadays, media that are mainly used are computers and the internet. The integration of both media is called multimedia. According to Hofstteter, multimedia refers to the utilization of computers to create and combine texts, graphs, audio, and moving pictures (video and animation) by connecting link and toll that allows the users to navigate, interact, create, and communicate. Halliday, (2000) stated that there are three aspects to assess the multimedia including (1) 
learning that refers to procedures and techniques to show or present the messages contained in learning material, (2) media that in this case are the selection and the utilization of media that can attract students' attention and interest, and (3) material referring to learning content or materials including information, motivation, orientation, and evaluation. While Daryanto (2010) stated that characteristics of a good learning media are: (1) combining more than one media like audio and video; (2) interactive, which means that is is able to accommodate responses from users, (3) independent, meaning that it is easy to use and the content is complete so that users can operate it without any assistance from others.

Android is an operating system that is developed for Linux based cellphones including operation systems, middleware, and open-source application. This operating system was firstly developed by Android Inc and followed by Google Inc in 2005 Suyanto, (2015). The functions of android are not limited only on a cellphone like Smartphone or Tablet but also on open source features that can be used or are applicable in various electronic devices like laptop, smart TV, camera, watches, Game console, DVD car player, and others (Poudel, 2013). The Android display is based on direct manipulation receiving input from various touches similar to actions in the real world like sweeping, tapping, pinching, and reversing pinch to manipulate objects on the screen (Kuo et al., 2017). Android provides an Open Platform to assist developers to develop their applications for some smartphone companies. Android can dominate the world of smartphones due to the many advantages it offers. Android has some features supporting the users including (1) A better capacity for various widgets to assist the users; (2) copy-paste and share it facilities for selected texts; (3) a faster Browser chrome that can be synchronized to the smartphone or computer; (4) clearer notifications, wider screen allowing Google to show the notifications on screens freely; (5) improvement on drag and drop and multitouch of screen is wider so that users can do drag and drop to move emails in Gmail app.

Android is better in Switching and is more multitasking so that it has better support for multitasking apps and now it is more improved, in honeycomb the users can easily move from one to another app only by tapping an icon in the bar system (Sulihati, 2016)
Operation system of Android according to Herawan, (2011) has some features including a framework app that facilitates the use and the movement of available components, Dalvik virtual machine, a virtual machine that is optimized for a mobile device, 2D and 3D graph that is based on library OpenGL, SQLite for storing data, media supporters e.g. audio, video, and various picture formats (MPEG4, H.264, $M P 3, A A C, A M R, J P G, P N G, G I F)$, data communication e.g. GSM, Bluetooth, EDGE, $3 G$ and WIFI, camera, GPS, Compass, and Accelerometer as well as application to develop the Android, like an emulator, debugging, and plugin for Eclipse IDE.

Based on observation and interviews carried out by the researchers in Vocational High School Kartika XX-1 Makassar, that A accredited school had been completed with facilities to support the activeness and creativeness of teachers and students in carrying out the learning process. However, those facilities had not been optimally occupied. Basically, teachers had used Microsoft PowerPoint for presentation media in teaching that presents pictures and texts, yet the learning process was still dominated by teachers' talk so that students' self-regulated learning had not been optimally developed. Of course, such a learning condition was unable to stimulate students' to think creatively and critically and to allow the learning process conducted anywhere and anytime. Therefore, a media that utilize information and communication technology that is easy to access needed to be developed.

One of the subjects generally raises problems among students is Physics that requires students to understand the surrounding environment including movement, material, energy, and force. The problem was that the learning process still tended to be verbalism, the explanation was rather abstract and there was no object available so that students did not understand the forms, shapes, or characteristics of objects. Physics explains learning various types of objects like the ones which are wide, big, small, or dangerous so that it needs aids to show the objects. Considering this condition and after doing a consultation with the subject teachers, the researcher would develop an interactive, innovative, efficient, and effective media using android or smartphone to help teachers in performing teaching activities at school so that learning can become more flexible. Based on a study carried out by 
Magnesen, (1983), we learn 10\% from what we read, $20 \%$ from what we listen, $30 \%$ from what we see, $70 \%$ from what we say, and $90 \%$ from what we do. Thus, when a teacher teaches by involving some activities, the teaching content will be more memorable for students. It can be achieved through the use of multimedia. Based on Quantum Learning theory, students have three different learning styles which are visual, auditorial, and kinesthetic. Those differences can be facilitated through the utilization of multimedia.

The use of android in smartphones for learning has become a trend nowadays moreover because it has been completed with features that can support the learning activities. Kitchenham, (2011) argues that one of the alternatives to develop a learning media with information technology is through the use of a smartphone. It is supported by Konstantin, (2014) that using a smartphone can assist students to discover wider and deeper learning resources through the internet, so that the learning can be more developed. Besides that, it can train the lab skills and build their competence dynamically because they are supported by the mobility of the smartphone.

The utilization of smartphones in education is known as mobile learning (m-learning) technology. McAdams-DeMarco et al., (2017) González et al., (2017) stated that the use of this media can assist students in accessing learning resources or it can function as learning media so that it positively contributes on students. Besides that, Pachler, (2007) believed that through the use of mobile media, smartphone, has a central role in delivering information.

This condition is supported by the continuous growth of smartphone users in Indonesia from year to year. Based on data from eMarketer Research Institution, it was projected that the users of the smartphone would dramatically increase until 2019, and would be the three highest users in the Asian Pacific region, that is after Tiongkok and India. In 2015, the smartphone users were still 55,4 million and would continually grow to 92 million in 2019(Pengguna Smartphone Di Indonesia 2016-2019 | Databoks, n.d.). Besides that, students have been $100 \%$ ready for digitalization and the use of the internet as found by Nurhikmah et al., (2019), that the average use of gadgets by senior high school students is more than 30 minutes. Based on various considerations above, the researchers would develop an android based multimedia for teaching Physics in Grade X, Vocational High School Kartika XX-1 Makassar.

The development of learning applications with an android based smartphone is expected to support students understanding materials about momentum. Based on the problems above, the purposes of this study are: (1) To describe the needs of android based multimedia development for Physics subject in Grade X, Vocational High School Kartika XX-1 Makassar; (2) To design the development of android based multimedia for Physics subject in Grade X, Vocational High School Kartika XX-1 Makassar; (3) To measure the validity and practicality of android based multimedia for Physics subject in Grade X, Vocational High School Kartika XX-1 Makassar.

\section{METHOD}

This study employed the Research and Development approach that is a method to create a product and to test the effectiveness of the product (Sukmadinata. 2010).

The planning model used in developing and designing the multimedia was Alessi \& Trollip, (2001) Model. It adapted the interactive multimedia development model developed by Stephen M. Alessia and Stanley R. Trollip. The stages are as follows: (1) Planning consisting of defining the scope, Identifying Learner Characteristics, Producing A Planning Document, Determining and Collecting Resources, and Conducting Initial Brainstorming; (2) Designing step consisting of Developing Initial Content Ideas, Conducting Task, and Concept Analyses, Doing a Preliminary Program Description, and Creating Flowcharts and Storyboards; (3) Development step consisting of preparing The Text, Producing Video, Assembling The Piece, Preparing Support Materials, Making a program, dan Testing, and Revising.

Based on the research problems, the study was carried out until testing the practicality of the product through small group trials. 


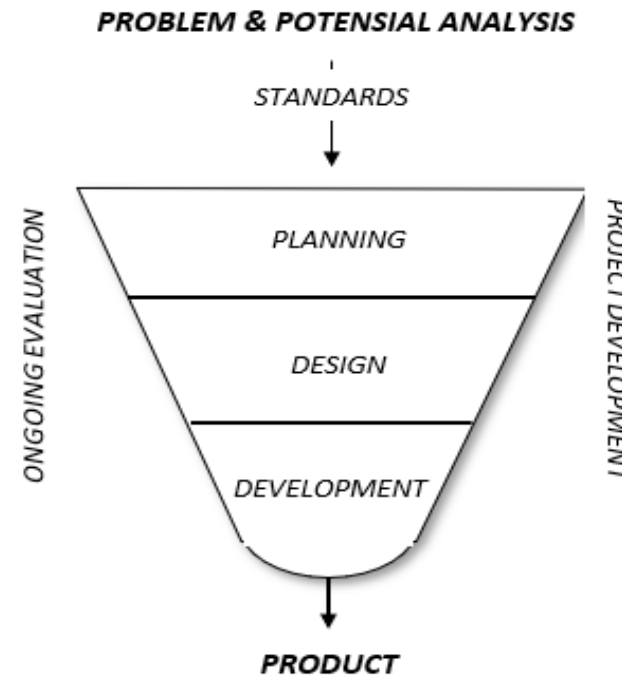

Figure 1. Research Stages

Subjects of this developmental study were 1 validator for learning content and 1 validator for teaching media. The individual trials involved 7 students and small group trials involved 25 persons divided into 5 small groups, and it also invited 1 subject teacher of Vocational High School Kartika XX-1 Makassar as a responder.

Data were collected through documentation, interviews, and questionnaires. Those data were categorized into 4 groups,: (1) data from first-stage evaluation including data from the expert of content and the expert of teaching media, (2) data from the second stage evaluation that is from individual testing, (3) data from the first stage evaluation that is from the small group testing, and (4) data from teacher's review.

All data that had been obtained were grouped into quantitative and qualitative categories. Qualitative data were obtained from documentation and interview to review the data from a content expert through response and interview questionnaires, data from review by experts and interviews, data from small group trials through interview questionnaires, interviews on teachers' reviews through response and interview questionnaires.

Next, data were analyzed descriptively through qualitative and statistical approaches. The qualitative descriptive analysis was used to process data from experts' reviews on the learning content, media, and learning design. It was carried out by grouping information from qualitative data including suggestions, responses, critiques, and advice obtained from questionnaires and interviews. The results of this analysis were then used to revise the teaching media product. While these analysis techniques were occupied to process data obtained from questionnaires in the form of percentage description.

The process to identify students' characteristics and contents or materials of learning media, individual trial questionnaire, small group trial questionnaire referred to Tegeh \& Kirna, (2010) as follows.

Table 2. Conversion of Achievement Level with Scale of 5

\begin{tabular}{ccc}
\hline $\begin{array}{c}\text { Achievement } \\
\text { level }\end{array}$ & Qualifications & $\begin{array}{c}\text { Need for } \\
\text { Revision }\end{array}$ \\
\hline $95 \%-100 \%$ & Very good & No \\
$75 \%-89 \%$ & Good & No \\
$65 \%-74 \%$ & Average & Yes \\
$55 \%-64 \%$ & Bad & Yes \\
$0 \%-54 \%$ & Very bad & Yes \\
\hline
\end{tabular}

\section{RESULTS AND DISCUSSION}

\section{Results}

This developmental study produced android based multimedia for teaching Physics at Grade X that can be used with a smartphone or tablet. The development of these products followed Alessi and Trollip Model consisting some stages including Planning, design, and development that is described in more detailed below:

a. Needs for Development

Based on observation and indirect interviews, we found that teachers had not maximally utilized the facilities available at school for teaching process like Wifi that could be accessed by all school communities. In the learning process, some teachers had utilized teaching media like PowerPoint containing text and pictures. However, some teachers still taught conventionally like focusing on speech so that the learning material was not effectively delivered. Whereas according to a questionnaire about students' characteristics and skills, they had the interest to use some media like audios, videos, and animation for learning.

The school gave authority to teachers to use a smartphone for teaching and learning to support those activities. The development of IT is signed by the existence of smartphone that 
assists people to communicate, to work, to enjoy entertainment, and even to study so that the education should update the development of the IT by creating innovative learning media in the form of multimedia that can help learners with different mobilities by the use of android based smartphone in accordance with the teaching goals as depicted in the syllabus and lesson plan. As the result, the learning process can be conducted anywhere and anytime. For a more detailed, each stage is explained in point 3 .

b. Developmental Design

The android based multimedia was designed by deciding the layout, font type and size, and color according to learners' preference to make it interesting for learning. Besides that, it is important to design the menu bar. The developer and the Physics teacher decided to name the application as "Fisikawan". The selection of the name aimed to increase students' interest to learn Physics.

Following that, the content was selected based on the core competences and basic competences. It was started by creating the material flow in the form of a conceptual map of temperature and color to ease the development of the android based multimedia learning. After that, a flowchart and storyboard were developed. Flowchart aimed to design the workflow of the android apps so that the product could be easier to design. The storyboard or image sketch was arranged according to post by post material to make them well organized. After that, the layout designs of the display, cover, text, videos, animations, and quizzes were planned. For more details, please refer to point 3 below.

c. Research Stage

To produce valid and practical android based multimedia learning, there were three stages to be followed adapted from Allesi and Trollip developmental model as detailly explained below:

1) Planning Stage

This step determined the learning goals. Materials developed in the product were based on the syllabus and lesson plan by considering the students' needs and characters according to information gathered from the questionnaire which indicated that they were interested in the use of media like audio, video, and animation for learning. $100 \%$ of students had mobile phones, and they used it $25 \%$ for games, $64 \%$ for social media, and only $4 \%$ for learning. This stage provided some documents including students' worksheets, multiple-choice tests, and questionnaires for validation and trials. This step also provided sources of materials, images, and videos related to the learning goals.

\section{2) Design Stage}

In this stage, before developing the product, we decided on the form, display, font size, and menu bar contents. After that, the materials of temperature and heat were provided in the form of a conceptual map. In this stage, some procedures were followed including developing the idea, analyzing the concept, creating an initial description, and creating a flowchart and storyboard.

The flowchart was to determine the workflow of the learning media with the core materials of temperature and heat. A storyboard was created to plan the display, cover, materials (text and videos), exercises, and practices.

\section{3) Developmental Stage}

This was the last step of the development of android based multimedia learning. This stage prepared the materials of temperature and heat in the forms of text, multiple-choice tests, and students' worksheets. After that, we prepared a video using Microsoft PowerPoint and Sparkol Videoscribe software. The material contents were made using Microsoft Powerpoint in the form of the slide by slide, after that, we did Record Slide Show to adjust the time per slide. It was then published into extension Windows Media Video (.wmv) while the learning video was made using Sparkol VideoScribe software and was published into MP4 format. The final learning videos were upload at www.materi.portalcbt.com.

To combine all learning material components, the developer used the Android studio and CMS WordPress software. After that, a supporting instrument was provided to improve the interactiveness of android based multimedia. In this case, a guidebook was provided for teachers and students. Following is the display of the android app that was developed.

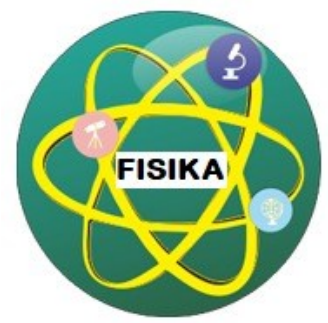

Figure 2. Icon 


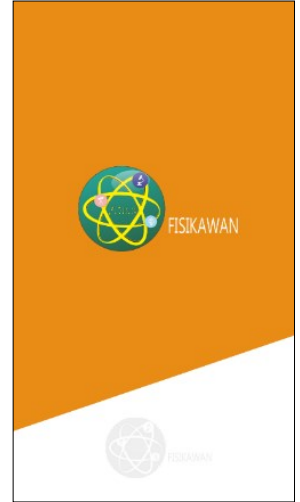

Figure 3. Opening Screen

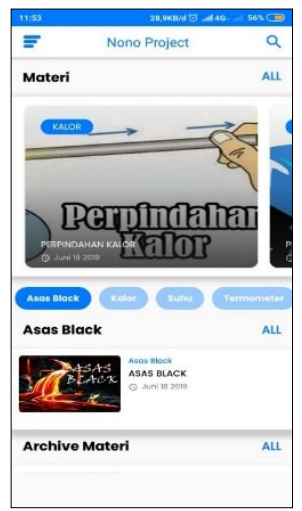

Figure 4. Main Screen

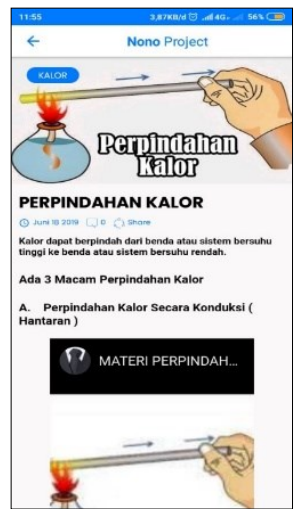

Figure 5. Materials

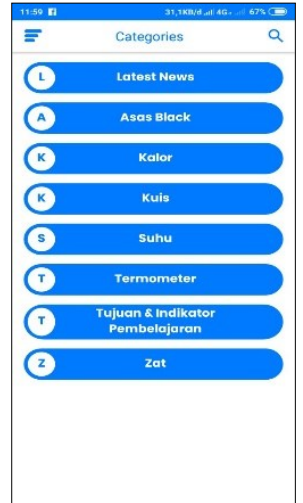

Figure 6. Categories

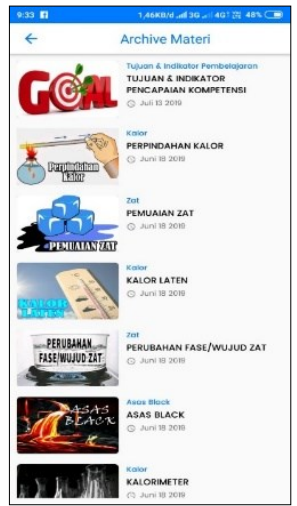

Figure 7. Material Archives

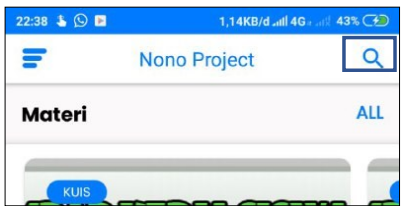

Figure 8. Search Screen

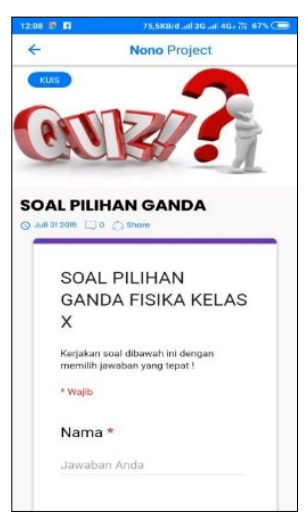

Figure 9. Multiple Choice Test 


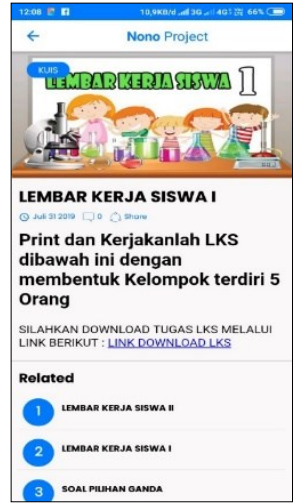

Figure 10. Student Worksheet

After finishing the program, the alpha test and validation test were performed by experts of content and teaching media.
Suggestions that we obtained from them included the need to add the identity of the product, to attach the learning goals, and to provide a manual book for teachers. Validation performed by experts of material and media is presented in table 1 showing the score of 69 with the achievement level of $99 \%$. This study was in line with Kuswanto \& Radiansah, (2018) that obtained a very good category and was feasible to be continued to the next step without revision yet needed to consider some suggestions to improve the quality of the product.

Table 1. Results of Assessments Performed by Experts of Learning Materials on Android Based Multimedia Learning

\begin{tabular}{|c|c|c|}
\hline No & Assessment Indicators & Scores \\
\hline \multicolumn{3}{|c|}{ Assessment } \\
\hline 1 & The materials are based on the curriculum & 4 \\
\hline 2 & The media can push students' independence in learning & 5 \\
\hline 3 & The application manual is easy to understand & 5 \\
\hline 4 & The application can support independent learning & 5 \\
\hline 5 & The language used is clear and appropriate & 5 \\
\hline 6 & The materials are based on students' characteristics & 5 \\
\hline 7 & Contents are interesting & 5 \\
\hline \multicolumn{3}{|c|}{ Content } \\
\hline 8 & Materials are presented clearly and briefly & 5 \\
\hline 9 & Materials have wide and deep coverage & 5 \\
\hline 10 & Materials are presented systematically according to indicators & 5 \\
\hline 11 & $\begin{array}{l}\text { Pictures, videos, and animation can help the users to understand questions } \\
\text { clearly }\end{array}$ & 5 \\
\hline \multicolumn{3}{|c|}{ Completeness, accuracy, and meaningfulness } \\
\hline 12 & Media cover the competencies & 5 \\
\hline 13 & Pictures, videos, and animations correspond to the content & 5 \\
\hline 14 & The application can stimulate students to understand the materials & 5 \\
\hline & Average & 69 \\
\hline
\end{tabular}

Based on findings presented in table 2 below, the media got a score of 128 with the achievement level of $95 \%$ indicating it to be qualified as 'very good and feasible' and could go through the next steps without revision. It was in line with studies carried out by Fatmala \& Yelianti, (2016) and Putri \& Muhtadi, (2018). 
Table 2. Results of Assessment Performed by Experts of Media on The Android Based Multimedia for Learning

\begin{tabular}{clc}
\hline No & \multicolumn{1}{c}{ Assessment Indicators } & Scores \\
\hline & \multicolumn{1}{c}{ Design } & \\
1 & The compatibility between product and design & 5 \\
3 & The consistency and proportionality of colors & 5 \\
4 & The compatibility between media and learning goals & 5 \\
5 & The compatibility between media and materials & 5 \\
6 & The compatibility between media and learning characteristics & 5 \\
7 & The compatibility of font type & 5 \\
8 & The contrast between texts and background & 5 \\
9 & The clarity of key and navigations & 4 \\
10 & Consistency and accuracy & 5 \\
\hline
\end{tabular}

\begin{tabular}{|c|c|c|}
\hline \multicolumn{3}{|c|}{ Display } \\
\hline 11 & The clarity of program identity & 4 \\
\hline 12 & The clarity of instructions for use & 4 \\
\hline 13 & Readability of paragraph order & 4 \\
\hline 14 & The proportionality of colors & 4 \\
\hline 15 & The clarity of pictures & 5 \\
\hline 16 & The clarity of animations & 5 \\
\hline 17 & The clarity of videos & 5 \\
\hline \multicolumn{3}{|c|}{ Usage } \\
\hline 18 & The ease of use & 5 \\
\hline 19 & The accuracy of key and navigation & 5 \\
\hline 20 & The ease to access the product menus & 5 \\
\hline 21 & The ease to do interaction with the product & 5 \\
\hline 22 & The ease to exit & 5 \\
\hline \multicolumn{3}{|c|}{ Utilization } \\
\hline 23 & The compatibility of program components & 5 \\
\hline 24 & The appropriateness of language use & 5 \\
\hline 25 & Materials update or contextuality & 4 \\
\hline 26 & $\begin{array}{l}\text { Visual attractiveness (colors, pictures, illustrations, and font type and } \\
\text { size }\end{array}$ & 5 \\
\hline 27 & The possibility to do self-assessment & 4 \\
\hline \multicolumn{2}{|r|}{$\begin{array}{c}\text { Total } \\
\end{array}$} & 128 \\
\hline
\end{tabular}

After being stated to be valid by the material expert and teaching media expert, we performed an individual beta test involving 7 respondents and a small group trial involving 27 respondents divided into 5 groups. Results of individual trials and groups are presented in tables $\quad 3$ and 4 below. 
Table 3. Results of Individual Trials

\begin{tabular}{|c|c|c|c|c|c|c|c|c|}
\hline \multirow{2}{*}{ No } & \multirow{2}{*}{ Assessment Aspects } & \multicolumn{7}{|c|}{ Respondents } \\
\hline & & R1 & $\mathbf{R 2}$ & $\mathbf{R 3}$ & R4 & R5 & R6 & R7 \\
\hline 1 & Quality of display & 5 & 5 & 5 & 4 & 4 & 4 & 5 \\
\hline 2 & Clarity of display & 5 & 5 & 5 & 5 & 5 & 5 & 5 \\
\hline 3 & Clarity of messages / materials & 5 & 4 & 4 & 5 & 5 & 5 & 5 \\
\hline 4 & $\begin{array}{l}\text { The ease to understand the } \\
\text { materials }\end{array}$ & 5 & 5 & 5 & 4 & 5 & 5 & 5 \\
\hline 5 & Readability of font sizes and types & 5 & 5 & 5 & 5 & 5 & 5 & 5 \\
\hline 6 & Clarity of language use & 4 & 5 & 4 & 5 & 4 & 4 & 5 \\
\hline 7 & Color contrast & 5 & 5 & 4 & 5 & 4 & 4 & 5 \\
\hline 8 & $\begin{array}{l}\text { The compatibility beween pictures } \\
\text { and materials }\end{array}$ & 4 & 4 & 4 & 4 & 5 & 5 & 5 \\
\hline 9 & $\begin{array}{l}\text { The compatibility beween videos } \\
\text { and materials }\end{array}$ & 4 & 4 & 5 & 5 & 5 & 5 & 5 \\
\hline 10 & $\begin{array}{l}\text { The compatibility beween } \\
\text { animations and materials }\end{array}$ & 5 & 4 & 5 & 5 & 5 & 5 & 5 \\
\hline 11 & Media attractiveness & 4 & 5 & 5 & 5 & 4 & 4 & 4 \\
\hline & $\begin{array}{r}\text { Total scores } \\
\end{array}$ & 51 & 51 & 51 & 52 & 51 & 51 & 54 \\
\hline & Percentages & $93 \%$ & $93 \%$ & $93 \%$ & $95 \%$ & $93 \%$ & $93 \%$ & $98 \%$ \\
\hline
\end{tabular}

Table 4. Results of Small Groups Trials

\begin{tabular}{|c|c|c|c|c|c|c|}
\hline \multirow{2}{*}{ No } & \multirow{2}{*}{ Assessment Aspects } & \multicolumn{5}{|c|}{ Respondents } \\
\hline & & K1 & K2 & K3 & K4 & K5 \\
\hline 1 & Quality of display & 5 & 5 & 5 & 5 & 5 \\
\hline 2 & Clarity of display & 5 & 5 & 4 & 5 & 5 \\
\hline 3 & Clarity of messages / materials & 5 & 4 & 4 & 5 & 4 \\
\hline 4 & The ease to understand the materials & 4 & 5 & 5 & 5 & 3 \\
\hline 5 & Readability of font sizes and types & 4 & 4 & 5 & 4 & 5 \\
\hline 6 & Clarity of language use & 5 & 5 & 4 & 4 & 5 \\
\hline 7 & Color contrast & 5 & 4 & 5 & 5 & 4 \\
\hline 8 & $\begin{array}{l}\text { The compatibility beween pictures } \\
\text { and materials }\end{array}$ & 4 & 5 & 5 & 5 & 5 \\
\hline 9 & $\begin{array}{l}\text { The compatibility between videos and } \\
\text { materials }\end{array}$ & 4 & 4 & 5 & 5 & 4 \\
\hline 10 & $\begin{array}{l}\text { The compatibility between } \\
\text { animations and materials }\end{array}$ & 5 & 5 & 5 & 5 & 5 \\
\hline 11 & Media attractiveness & 5 & 4 & 4 & 5 & 5 \\
\hline & Total scores & 51 & 50 & 51 & 53 & 51 \\
\hline & Percentages & $93 \%$ & $91 \%$ & $93 \%$ & $96 \%$ & $91 \%$ \\
\hline
\end{tabular}

Based on table 3 above, the results of individual trials using questionnaires show the very good average scores. The average of all percentages of the android based multimedia was $94 \%$ categorized as "very good". Thus, the media was feasible for learning and did not need any revision. In table 4, it can be seen that the assessment from small group trials shows an average of $93 \%$. It is similar to the one conducted by Novianto et al., (2019) that also obtained a very good qualification thus it was valid and feasible to be continued to the next step. After performing individual trials and small group trials, we sought the subject teacher's response. The questionnaire he/she had completed showed that the average percentage of the learning multimedia was 100 indicating that it had a very good qualification and was feasible to be developed. The results of the 
Physics teacher's assessment can be seen in Table 5 below.

Table 5. Results of Assessment from The Subject Teacher

\begin{tabular}{clc}
\hline No & \multicolumn{1}{c}{ Assessment Aspects } & Scores \\
\hline 1. & The android - based learning media eases teachers to deliver the learning goals & 5 \\
2. & The android - based learning media can activate students in learning & 5 \\
3. & The android - based learning media corresponds with students' characteristics & 5 \\
4. & The android - based learning media is appropriate with materials it presents & 5 \\
5. & The presentation of the material is clear & 5 \\
6. & The display quality of the android - based learning media is very good & 5 \\
\hline & Total score & $\mathbf{3 0}$ \\
\hline
\end{tabular}

After performing trials and assessments on interactive multimedia, we found some weaknesses of the product like the cost related to an internet connection (internet data) as it can be only accessed online. Besides that, it also needs annual server cost for sustainable use. However, the problem related to internet cost can be solved by the use wifi connection provided by the school and the server cost can be charged to the school so that the multimedia can be occupied for learning activities.

\section{Discussion}

This study produced an interactive application using the Android system that could be used in smartphones with the android system. The product has been valid and feasible after being developed according to the needs of students at Vocational High School XX-1 Makassar obtained from the need assessment conducted to them. In other words, this product has very practical use so that students are easy to utilize. This product was exclusively developed for Physics subject for vocational high school. It was a new finding for vocational high school learning since the learning materials were packaged using Android Studio and CMS WordPress software. Furthermore, the supporting tool which in this case is the manual books for students and teachers can improve the interactivity of android based multimedia

The learning product developed in this study had passed the alpha and beta tests. The alpha test that was performed by the media expert and material expert showed that the media was very feasible and valid, while the content expert concluded that the content was in the feasible category and was ready for the next step. Betha test had two stages namely individual trial and small group trial. Both tests showed the "very feasible" category.

Individual test, according to table 3, showed that the average score was $93 \%$. The score indicated that the display, materials, language use, and color combination were students' and teachers' expectations so that it could motivate students to learn. It was in line with (Heinich, 1996) stating that clear explanation and accurate materials can improve students' motivation to learn and boost their participation during the learning process. The use of proper and effective teaching methods can increase students' learning results and the utilization of a media that can be held like a handphone can motivate students' to continuously involve in learning activities (Sung \& Mayer, 2013).

Multimedia with good feasibility can stimulate students to actively participate, can cover various students' learning styles, evoke students' motivation through the use of great colors, graphics, sounds, music, animations, and videos, are more interactive through the availability of keys, have consistent displays, and can be easily controlled by students (Newby et al., 2006). Media that was developed in this study can be used by students independently anywhere and anytime. In line with that, (Donnelly et al., 2010), mentioned that android based multimedia for learning are effective when they combine texts, graphics, audios, and moving pictures (videos and animations) so that students can control it by themselves like navigating it, switching materials, playing and pausing videos, and replaying animation or video contents available in that android based app. 
Information about students' needs was obtained from observation on students and indirect interviews conducted to teachers. In the initial observation, we identified that learning in the classroom used Microsoft PowerPoint to present text and pictures but it was still less interesting for students. The school had been already facilitated with wifi that could become sources of learning materials but was not maximally utilized by students and teachers. The development of IT is indicated by the use of the smartphone by all society levels especially people aged between 15-17 years.

The infrequent use of smartphones for learning purposes was also reported by a survey carried out by PUSLITBANG (Indonesian Research and Development Center) KOMINFO (Ministry of Communication and Informatics). KOMINFO, (2017) mentioned that observation and interviews carried out in a number of schools discovered that the information and communication technologies especially smartphones had not been optimally used by teachers, especially for Physics subjects. Indeed, the subject needed many laboratory tools and materials. Based on that report, we developed multimedia for learning that could facilitate all students' learning styles according to the theory of Quantum Learning (Riyana, Rusman \& Kurniawan, 2011).

Although the android based media has some limitations like the continuous use of the internet, it can be solved by utilizing wifi that had been provided by the school or in other public places. However, we should consider that the interactive multimedia can be effective if the materials are presented not only using text and pictures, but also animation and videos. It is to cover all students' learning styles. A BAVA study by (Rusman, 2018), emphasized that the use of multimedia in teaching can increase the absorption of knowledge and it can remain longer in students' memory. Besides that, the multimedia product developed in this study has fulfilled the criteria of Self Instruction, Self Contained, Adaptive, Stand Alone, and User Friendly so that it can boost students' attention and motivation and increase the quality of learning.

\section{CONCLUSIONS AND SUGGESTIONS}

In conclusion, (1) the use of the internet in learning had not been maximum yet, including the use of the smartphone, while the development of information technology requires the use of such devices in learning; (2) Android - based multimedia that was developed had been validated by experts of content and teaching media and it was stated that it is valid and very feasible to be utilized; (3) individual trial resulted in scores in the "very feasible" so that it is considered to be valid, while the small group trials showed score in the "very valid and practical" category. Based on the stages followed in the development of android based multimedia for Physics, it is recommended to continue to develop the product to the next stages namely big group trials and implementation.

\section{REFERENCES}

Alessi, S. M., \& Trollip, S. R. (2001). Multimedia for learning: Methods and development. Allyn \& Bacon.

Daryanto, D. (2010). Media pembelajaran. Yogjakarta, Gava Media.

Donnelly, M., Nugent, C., McClean, S., Scotney, B., Mason, S., Passmore, P., \& Craig, D. (2010). A Mobile Multimedia Technology to Aid Those with Alzheimer. IEEE Multimedia, 2, 42-51.

Fatmala, D., \& Yelianti, U. (2016). Pengembangan media pembelajaran multimedia interaktif berbasis android pada materi plantae untuk siswa SMA menggunakan Eclipse Galileo. BIODIK, 2(1).

González, M. Á., González, M. Á., Martín, M. E., Llamas, C., Martínez, Ó., Vegas, J., Herguedas, M., \& Hernández, C. (2017). Teaching and learning physics with smartphones. In Blended Learning: Concepts, Methodologies, Tools, and Applications (pp. 866-885). IGI Global.

Halliday, J. (2000). Instructional Technology for Teaching and Learning: Designing Instruction, Integrating Computers, and Using media. International Forum of Educational Technology \& Society.

Heinich, R. (1996). Instructional media and technologies for learning. Simon \& Schuster Books For Young Readers.

Herawan, Y. (2011). Membuat Aplikasi Android Sendiri. 
Kitchenham, A. (2011). Models for interdisciplinary mobile learning: delivering information to students. Information Science Reference.

Kominfo. (2017). Survey Penggunaan TIK Serta Implikasinya Terhadap Sosial Budaya Masyarakat. Badan Penelitian Dan Pengembangan Sumber Daya Manusia, 130.

Konstantin, R. (2014). Physics Learning Instruments of XXI Century. Proceedings of the World Conference on Physics Education 2012, 2014 Ankara, Turkey, 913-923.

Kuo, A. F., Hwang, G., Chen, S., Chen, S. Y., Journal, S., \& Learning, A. (2017). International Forum of Educational Technology \& Society A Cognitive Apprenticeship Approach to Facilitating Web-based Collaborative Problem Solving Published by: International Forum of Educational Technology \& Society Linked references are available on J. 15(4).

Kuswanto, J., \& Radiansah, F. (2018). Media Pembelajaran Berbasis Android Pada Mata Pelajaran Sistem Operasi Jaringan Kelas XI. Jurnal Media Infotama, 14(1).

Magnesen, V. A. (1983). A Review of Findings from Learning and Memory Retention Studies. Innovation Abstracts, 5(25).

McAdams-DeMarco, M. A., Konel, J., Warsame, F., Ying, H., Fernández, M. G., Carlson, M. C., Fine, D. M., Appel, L. J., \& Segev, D. L. (2017). Intradialytic Cognitive and Exercise Training May Preserve Cognitive Function. Kidney International Reports, September, 1-8. https://doi.org/10.1016/j.ekir.2017.08.006

Miarso, Y. (2004). Menyemai benih teknologi pendidikan. Kencana.

Newby, T. J., Stepich, D. A., Russell, J. D., \& Lehman, J. D. (2006). Educational technology for teaching and learning. Prentice Hall.

Novianto, L. A., Degeng, I. N. S., \& Wedi, A. (2019). Pengembangan Multimedia Interaktif Mata Pelajaran IPA Pokok Bahasan Sistem Peredaran Darah Manusia Untuk Kelas VIII SMP Wahid Hasyim Malang. Jurnal Kajian Teknologi Pendidikan, 1(3), 257-263.
Nurhikmah, H., Hakim, A., Muin, A., \& Ramli, A. M. (2019). Define the Scope and Identify Learner Characteristics Computer Based Test ( CBT ) for Junior High School Students in Makassar. 372(ICoET), 320324.

Pachler, N. (2007). Mobile learning: towards a research agenda.

Pengguna Smartphone di Indonesia 2016-2019 | Databoks. (n.d.). Retrieved August 19, 2020,

Poudel, A. (2013). Mobile application development for Android operating system: case NepGuide Mobile.

Putri, D. P. E., \& Muhtadi, A. (2018). Pengembangan multimedia pembelajaran interaktif kimia berbasis android menggunakan prinsip mayer pada materi laju reaksi. Jurnal Inovasi Teknologi Pendidikan, 5(1), 38-47.

Riyana, Rusman, A., \& Kurniawan, C. D. (2011). Pembelajaran Berbasis Teknologi Informasi dan Komunikasi: Mengembangkan Profesionalitas Guru.

Rusman. (2018). Manajemen kurikulum (5th ed.). Rajawali Pers.

Sulihati, A. (2016). Aplikasi Akademik Online Berbasis Mobile Android Pada Universitas Tama Jagakarsa, Volume XI, Nomor 1, Hal 18-19. Universitas Tama. Jagakarsa.

Suyanto, A. H. (2015). Pengenalan E-learning. http://www.asep-hs.web.ugm.ac.id

Sung, E., \& Mayer, R. E. (2013). Online multimedia learning with mobile devices and desktop computers: An experimental test of Clark's methodsnot-media hypothesis. Computers in Human Behavior, 29(3), 639-647.

Tegeh, I. M., \& Kirna, I. M. (2010). Metode penelitian pengembangan pendidikan. Singaraja: Universitas Pendidikan Ganesha. 